\title{
The Effect on Activated Sludge of Chemical Coagulants Applied in Synchronization Dephosphorization
}

\author{
Yasong Chen \\ Beijing Construction Engineering Group (BCEG) Environment Development CO. LTD, Beijing, China \\ Email: chenyasong@gmail.com \\ Received September $18^{\text {th }}, 2013$; revised October $16^{\text {th }}, 2013$; accepted November $15^{\text {th }}, 2013$ \\ Copyright (C) 2013 Yasong Chen. This is an open access article distributed under the Creative Commons Attribution License, which \\ permits unrestricted use, distribution, and reproduction in any medium, provided the original work is properly cited. In accordance of \\ the Creative Commons Attribution License all Copyrights (C) 2013 are reserved for SCIRP and the owner of the intellectual property \\ Yasong Chen. All Copyright (C) 2013 are guarded by law and by SCIRP as a guardian.
}

\begin{abstract}
Combined with the practical experience of wastewater treatment plant, the chemical coagulants have inhibition effects on microorganism activity, with the influence degree of PAC (polyaluminium chloride) $>\mathrm{AlCl}_{3}>\mathrm{Fe}_{2}\left(\mathrm{SO}_{3}\right)_{3}$. In synchronization dephosphorization, the inhibition rates of PAC in $10 \mathrm{ppm}$ and $20 \mathrm{ppm}$ are $11.9 \%$ and 33\% respectively; while the inhibition rates of $\mathrm{AlCl}_{3}$ and $\mathrm{Fe}_{2}\left(\mathrm{SO}_{4}\right)_{3}$ in $20 \mathrm{ppm}$ are $15.8 \%$ and $8.5 \%$ respectively, compared with $9.6 \%$ and $5.4 \%$ in 10 ppm. Backwash wastewater from sand filter after adding coagulants has no direct inhibition effect on microorganism, but it results in inorganic components increase in active sludge. By taking North STP as an example, the VSS/SS ratio reduced from 0.65 after coagulants application to 0.54 .
\end{abstract}

Keywords: Synchronization Dephosphorization; Chemical Coagulants; Oxygen Uptake Rate (OUR); Activated Sludge

\section{Introduction}

With discharge standard for municipal wastewater treatment plant becoming stricter, 1A discharge standard in Discharge Standard of Pollutants for Municipal Wastewater Treatment Plant (GB18918-2002) has been extensively executed in China. Traditional biological dephosphorization technology cannot meet the new discharge standard any more and chemical coagulation method is added into upgraded and improved technology to assist dephosphorization [1]. As for wastewater treatment plants that have not been upgraded and improved, it is also an important treatment countermeasure to intensify dephosphorization by adding coagulants into biochemical system [2]. Then coagulant has two effects on microorganism: the first one is biological inhibition of direct addition on biochemical system; the other one comes to indirect influence of chemical sludge and residual coagulant cycle formed by advanced treatment on biochemical system. The inhibition influence of coagulant on microorganism has already drawn people's attention [3,4], and its influence degree is related to the applied treatment process, dosing method and coagulant type.

Coagulant of PAC (polyaluminium chloride) is adopted by North sewage treatment plant (North STP) in the city of Suzhou to assist dephosphorization. Two kinds of dosing methods were used, with one adding PAC to biochemical system before finally clarifier and the other one adding PAC to outflow after clarifier promoting coagulating in static mixer. There is no coagulating sedimentation tank before sand filter, which results in the fact that backwash wastewater from sand filter directly discharges into inlet pumping station and finally chemical sludge in backwash wastewater circulates into biochemical system. In order to verify and evaluate effects of coagulant on biochemical system, the influences of coagulant type and dosage on microorganism are studied and effects of longterm cycle of chemical sludge in biochemical system on microorganism are analyzed in this paper.

\section{Material and Method}

\subsection{Technical Flowchart}

AAO biological treatment process is adopted by North STP with a scale of $100,000 \mathrm{~m}^{3} / \mathrm{d}$. Meanwhile $1 \mathrm{~A}$ discharge standard is executed, in which total phosphorus of outflow is below $0.5 \mathrm{mg} / \mathrm{L}$. The technical flowchart is shown in Figure 1. 


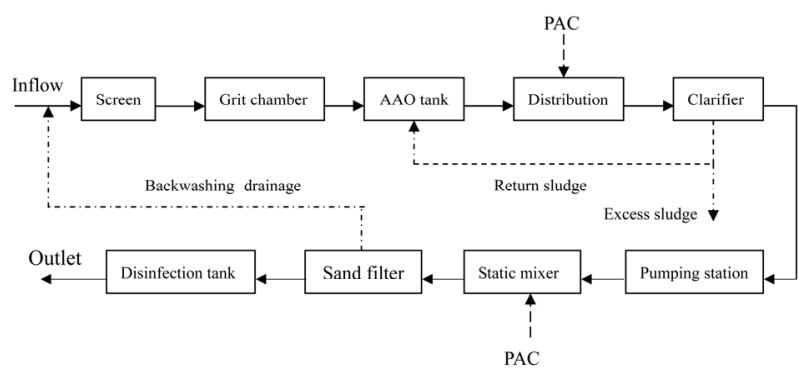

Figure 1. Technical flowchart of the North STP in Suzhou.

\subsection{Measurement for Oxygen Uptake Rate}

Fresh activated sludge is taken from the middle part of biochemical pool, coagulant (PAC, $\mathrm{AlCl}_{3}, \mathrm{Fe}_{2}\left(\mathrm{SO}_{4}\right)_{3}$ ) or backwash wastewater is added in different concentration ratios $(10-35 \mathrm{ppm})$, and the oxygen uptake rate (OUR) of microorganism in the sewage plant is measured rapidly. In order to maintain consistency of measurement environment, one blank contrast is taken from the same batch for simultaneous measurement, with reaction bulb and stirrer unchanged. The same brand and model should be used for dissolved oxygen measurement. The dissolved oxygen value in reactor reduces from $\mathrm{DO}_{1}$ to $\mathrm{DO}_{2}$ as the extension of time. The OUR is calculated as: OUR $=\left(\mathrm{DO}_{1}-\mathrm{DO}_{2}\right) /$ Time .

\subsection{Measurement Methods for Key Indexes}

Analysis of water conventional index refers to Water and Wastewater Monitoring Analysis Method (Version 4). Inductively Coupled Plasma Atomic Emission Spectrometry is adopted for total aluminum ( $\mathrm{Al}$ ) analysis in water. Total aluminum (Al) analysis in sludge refers to General Rule for Inductively Coupled Plasma Atomic Emission Spectrometry (JY/T015-1996). The VSS/SS ratio means volatile suspended sludge concentration to suspended sludge concentration.

\section{Result and Discussion}

\subsection{Effect of Aluminum Salt Coagulant on Microorganism Activity}

Considering Aluminum salt is the most common coagulants, $\mathrm{AlCl}_{3}$ and PAC are firstly selected to measure the OUR change of microorganism. In order to evaluate the direct influence of different coagulants on microorganism activity, effects of $\mathrm{AlCl}_{3}$ and PAC on microorganism activity are presented in Figures $\mathbf{2}$ and 3, according to different addition concentrations (calculated in $\mathrm{Al}$ ).

The figures show that a good linear relation is presented in change of OUR. The higher concentration of dosage has greater effect on OUR. When $\mathrm{AlCl}_{3}$ dosage is $15 \mathrm{ppm}$ and $35 \mathrm{ppm}$, OUR reduces from $0.582 \mathrm{mg} /$ (L·min) of blank sample to $0.487 \mathrm{mg} /(\mathrm{L} \cdot \mathrm{min})$ and 0.305

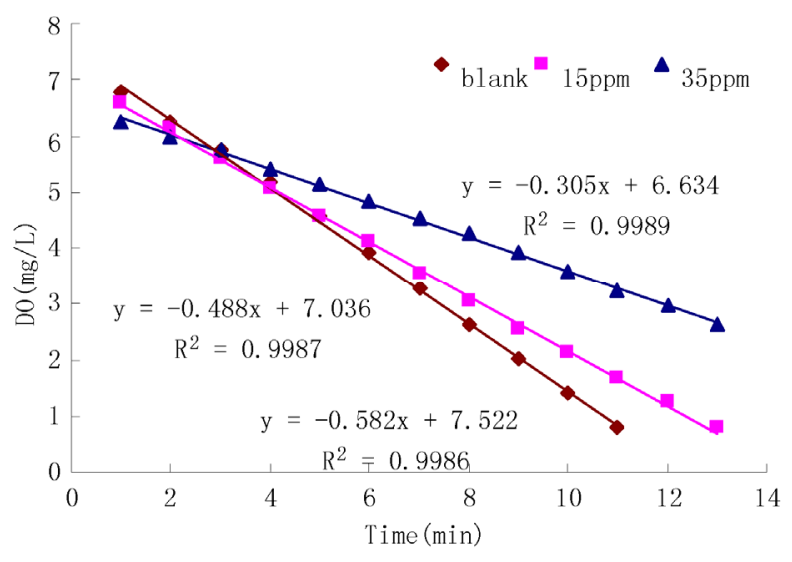

Figure 2. Effect of $\mathrm{AlCl}_{3}$ on microorganism activity.

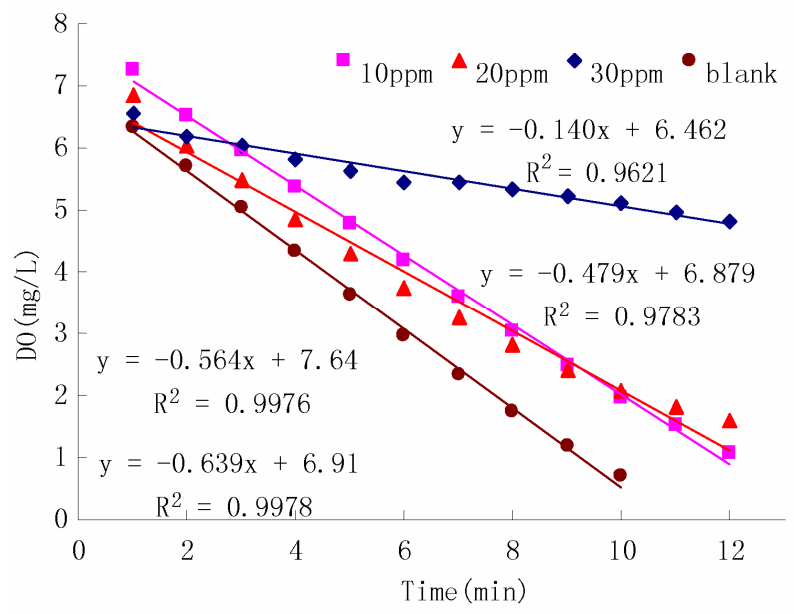

Figure 3. Effect of PAC on microorganism activity.

$\mathrm{mg} /(\mathrm{L} \cdot \mathrm{min})$ respectively, with the average inhibition rates of $16.1 \%$ and $45.7 \%$ separately. When PAC dosage is $10 \mathrm{ppm}, 20 \mathrm{ppm}$ and $30 \mathrm{ppm}$, the average inhibition rates are $11.9 \%, 33.0 \%$ and $80.1 \%$ respectively. Therefore, Aluminum salt coagulant has direct inhibition effect on microorganism. The inhibition effect of PAC is 3 times more than that of $\mathrm{AlCl}_{3}$, and coagulant with higher concentration dosage also has higher inhibition rate on microorganism. It is generally recommended that during direct application to biochemical pool for dephosphorization, the dosage should be less than $10 \mathrm{ppm}$, so as to decrease the inhibition effect as far as possible.

\subsection{Effect of Iron Salt Coagulant on Microorganism Activity}

Although the precipitate composed of iron salt and phosphate is more stable and has better effect when compared with aluminum salt, its application alone is restricted owing to its characteristics of tolerating $\mathrm{pH}$ and coloring outlet water. However, coagulant composed of aluminum and iron has attracted much attention and 
gained extensive application [5]. In order to select the best dephosphorization coagulant, contrast test is conducted for the effect on microorganism activity by using $\mathrm{Fe}_{2}\left(\mathrm{SO}_{4}\right)_{3}$ and $\mathrm{AlCl}_{3}$ under the concentration of $10-20$ ppm, calculated in aluminum or iron ions.

Figure 4 shows that when $\mathrm{AlCl}_{3}$ and $\mathrm{Fe}_{2}\left(\mathrm{SO}_{4}\right)_{3}$ are added in a concentration of $10 \mathrm{ppm}$, OUR of microorganism reduces from $0.575 \mathrm{mg} /(\mathrm{L} \cdot \mathrm{min})$ of blank sample to $0.446 \mathrm{mg} /(\mathrm{L} \cdot \mathrm{min})$ and $0.499 \mathrm{mg} /(\mathrm{L} \cdot \mathrm{min})$ respectively. Inhibition rate by $\mathrm{AlCl}_{3}$ is $9.6 \%$, compared with $5.4 \%$ by $\mathrm{Fe}_{2}\left(\mathrm{SO}_{4}\right)_{3}$. When $\mathrm{AlCl}_{3}$ and $\mathrm{Fe}_{2}\left(\mathrm{SO}_{4}\right)_{3}$ in a concentration of $20 \mathrm{ppm}$ are added, OUR of microorganism reduces from $0.69 \mathrm{mg} /(\mathrm{L} \cdot \mathrm{min})$ of blank sample to $0.475 \mathrm{mg} /$ $(\mathrm{L} \cdot \mathrm{min})$ and $0.576 \mathrm{mg} /(\mathrm{L} \cdot \mathrm{min})$ respectively as shown in Figure 5, with the inhibition rates by $\mathrm{AlCl}_{3}$ and $\mathrm{Fe}_{2}\left(\mathrm{SO}_{4}\right)_{3}$ of $15.8 \%$ and $8.5 \%$ separately. Therefore, inhibition rate to microorganism by $\mathrm{Fe}_{2}\left(\mathrm{SO}_{4}\right)_{3}$ is far lower than that by $\mathrm{AlCl}_{3}$. When the dosage is $10 \mathrm{ppm}$, inhibition effects of both aluminum salt and iron salt are small, with the inhibition rates of $9.6 \%$ and $5.4 \%$ respectively. In order to reduce effects of coagulant on biochemical system, iron salt, rather than aluminum salt, should be adopted when coagulant is directly added into biochemical system, and the dosage should be less than $20 \mathrm{ppm}$.

\subsection{Effect of Chemical Dephosphorization Sludge on Biochemical System}

In many sewage treatment plants, chemical coagulants are used for dephosphorization in advanced treatment process, which produces chemical dephosphorization

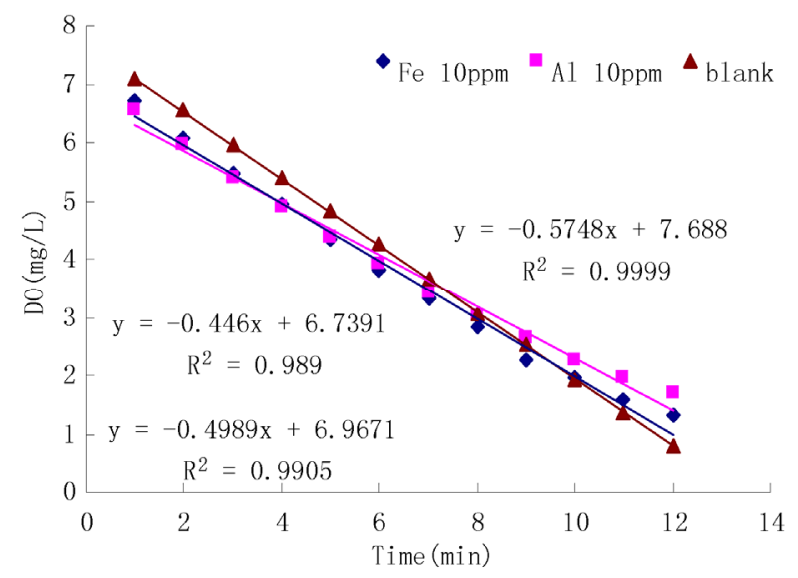

Figure 4. Comparison of effects on microorganism activity between aluminum salt and iron salt (10 ppm). sludge. The chemical sludge often directly discharges into inlet pumping station without sedimentation, and then chemical sludge will circulate into biochemical system. For instance, backwash wastewater (sludge) from the sand filter of North STP discharges into the inlet pumping station and circulates into the biochemical system, which has caused indirect effect on biochemical system. On the one hand, microorganism will be inhibited by backwash wastewater because of residual coagulant; on the other hand, inorganic components of activated sludge will be increased in biochemical pool owing to accumulation of chemical sludge. By taking North STP as an example, the backwashing wastewater volume of North STP occupies about $2.7 \%$ of the mixed water volume. In order to analyze its influence degree, mixed liquor, supernate and primary settling sludge are taken to test microorganism activity based on this proportion. The results are shown in Table $\mathbf{1 .}$

The above table presents that mixed liquor, supernate and primary settling sludge all have no effect on OUR of activated sludge when added into the activated sludge in a certain proportion. The results show that backwash wastewater has no direct influence on microorganism activity. Since aluminum salt has inhibition effect on microorganism activity, aluminum contents in pool water sample, backwash wastewater sample, activated sludge and chemical sludge of North STP are measured respectively in order to further analyze the reasons, as shown in Table 2.

The result shows that free aluminum concentration in

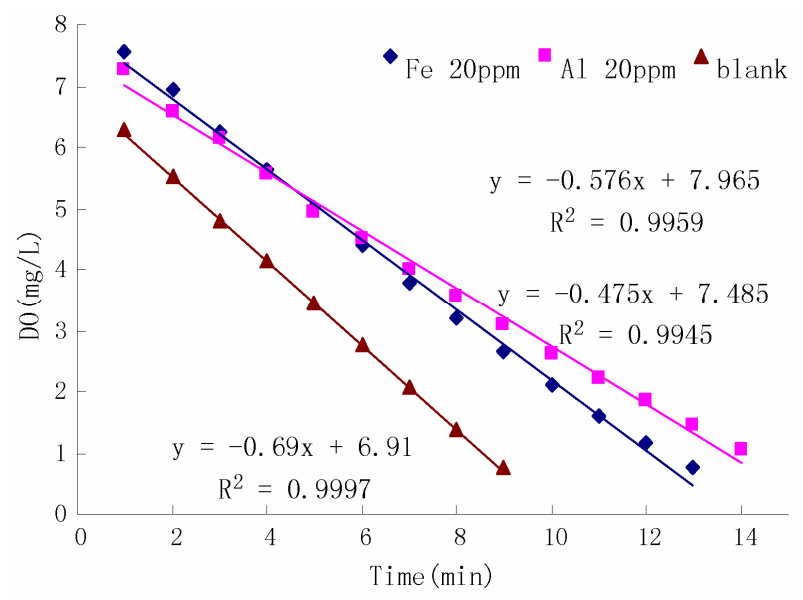

Figure 5. Comparison of effects on microorganism activity between aluminum salt and iron salt $(20 \mathrm{ppm})$.

Table 1. Effect of backwash wastewater on microorganism activity.

\begin{tabular}{ccccc}
\hline \multirow{2}{*}{ Item } & & & Addition with a proportion of 3\% \\
\cline { 2 - 4 } & Blank 1 & Mixed liquor & Blank 2 & Supernate \\
\hline OUR $(\mathrm{mg} /(\mathrm{L} \cdot \mathrm{min}))$ & 0.663 & 0.666 & 0.628 & 0.627 \\
\hline
\end{tabular}


the biochemical pool is quite low $(<0.025 \mathrm{mg} / \mathrm{L})$ and free aluminum concentration in backwash wastewater is only $0.489 \mathrm{mg} / \mathrm{L}$, which will not affect microorganism activity. Total aluminum content in sludge is $40.3 \mathrm{~g} / \mathrm{kg}$ in chemical sludge, compared with $24.2 \mathrm{~g} / \mathrm{kg}$ in activated sludge of biological treatment system, for aluminum salt has formed relatively stable compound. Long-term discharge of backwash wastewater into biochemical system has also made aluminum salt content in sludge of biological pool increase to $24.2 \mathrm{~g} / \mathrm{kg}$. Therefore, in chemical dephosphorization treatment of advanced treatment process, relatively stable precipitate will be formed by coagulant through coagu-flocculation reaction and the free aluminum salt content is quite low, which won't affect microorganism activity. Backwash wastewater almost has no effect on toxicity of microorganism, but it has obviously increased inorganic components in activated sludge.

Another influence of discharging a large amount of chemical sludge is increase of inorganic components in activated sludge and decrease of microorganism activity under unit sludge concentration. By taking actual operating data of North STP as an example, dosage of PAC in advanced treatment process is $6-10 \mathrm{mg} / \mathrm{L}$, producing chemical sludge about $2 \mathrm{t} / \mathrm{d}$. Daily output of dry sludge in the plant is about 16t, including chemical sludge of $2 \mathrm{t}$ and biological sludge of $14 \mathrm{t}$. The production proportion between chemical sludge and biochemical sludge is 1:7. After long-term operation and accumulation, chemical sludge enters biochemical pool and finally reaches a balance. Suppose that inorganic component occupies $80 \%$ of chemical sludge, and then the ultimate VSS/SS of activated sludge in biochemical pool will reduce by $10.3 \%$ when compared with pure activated sludge. Table 3 shows the comparison result between actually measured value and theoretical value in VSS/SS of activated sludge in biochemical pool before chemical dephosphorization (2008) and after chemical dephosphorization (2010).

Obviously, after chemical sludge enters biochemical system, inorganic components in activated sludge in- crease, while the VSS/SS reduces from 0.65 before to 0.54 . The result is approximate to theoretical derivation. Therefore, when chemical coagulants are applied to dephosphorization in a large amount, the more the chemical sludge is, the lower the VSS/SS value will be. In order to avoid decrease in microorganism activity under unit concentration, sludge discharge methods can be adjusted and fresh activated sludge used as replacement according to the cycle of sludge age. In another word, sludge can discharge in a large amount at earlier stage and sludge discharge can be reduced later in a cycle of sludge age. In circulation like this, sludge generated in chemical process will be replaced by newly produced biological sludge, thus VSS/SS can be increased and microorganism activity recovered.

\section{Conclusions}

1) $\mathrm{AlCl}_{3}, \mathrm{Fe}_{2}\left(\mathrm{SO}_{4}\right)_{3}$ and $\mathrm{PAC}$ in different concentrations have inhibition effects on microorganism, with the influence degree of $\mathrm{PAC}>\mathrm{AlCl}_{3}>\mathrm{Fe}_{2}\left(\mathrm{SO}_{4}\right)_{3}$. The inhibition rates of PAC in $10 \mathrm{ppm}$ and $20 \mathrm{ppm}$ are $11.9 \%$ and $33 \%$ respectively; while the inhibition rates of $\mathrm{AlCl}_{3}$ and $\mathrm{Fe}_{2}\left(\mathrm{SO}_{4}\right)_{3}$ in $20 \mathrm{ppm}$ are $15.8 \%$ and $8.5 \%$ respectively, compared with $9.6 \%$ and $5.4 \%$ in $10 \mathrm{ppm}$.

2) When coagulant is directly added into biochemical system for dephosphorization, iron salt coagulant has better effect than aluminum salt and PAC. The dosage of iron salt should be less than $20 \mathrm{ppm}$ and aluminum salt coagulant should be controlled within $10 \mathrm{ppm}$, so as to reduce their influence on microorganism activity as far as possible. Therefore, it is suggested that PAC applied in North STP should be replaced by iron salt coagulant or coagulant composed of iron and aluminum.

3) Backwash wastewater from sand filter has no direct inhibition effect on microorganism after discharge into biochemical system. The main reason is that stable precipitate will be formed by coagulant and phosphate, and free aluminum ion has a low concentration in water.

4) After backwash wastewater discharges into bio-

Table 2. Comparison of aluminum ion concentration among water samples.

\begin{tabular}{|c|c|c|c|c|}
\hline \multirow{2}{*}{ Item } & \multicolumn{2}{|c|}{ Water sample $(\mathrm{mg} / \mathrm{L})$} & \multicolumn{2}{|c|}{ Sludge sample (g/kg) } \\
\hline & Biochemical pool water & Backwash wastewater & Activated sludge & chemical sludge \\
\hline Total aluminum content (calculated in $\mathrm{Al}$ ) & $<0.025$ & 0.489 & 24.2 & 40.3 \\
\hline
\end{tabular}

Table 3. Change of VSS/SS in activated sludge.

\begin{tabular}{ccccc}
\hline \multirow{2}{*}{ Item } & \multicolumn{2}{c}{ Actually measured value } & \multicolumn{2}{c}{ Theoretical value } \\
\cline { 2 - 5 } & $\begin{array}{c}\text { Before chemical } \\
\text { dephosphorization }\end{array}$ & $\begin{array}{c}\text { After chemical } \\
\text { dephosphorization }\end{array}$ & $\begin{array}{c}\text { Before chemical } \\
\text { dephosphorization }\end{array}$ & $\begin{array}{c}\text { After chemical } \\
\text { dephosphorization }\end{array}$ \\
\hline VSS/SS value & 0.65 & 0.54 & 0.65 & 0.583 \\
\hline
\end{tabular}


chemical system, inorganic components in activated sludge of biochemical system will increase, thus microorganism activity under unit concentration will decrease. VSS/SS value of North STP reduces from 0.65 before to 0.54 . Therefore, when chemical coagulants are applied to dephosphorization in a large amount, the more the chemical sludge is, the lower the VSS/SS value will be. In order to avoid decrease in microorganism activity under unit concentration, sludge discharge methods can be adjusted and fresh activated sludge used as replacement according to the cycle of sludge age.

\section{Acknowledgements}

The research work was supported by National Science and Technology Project of China and Scientific and Technological Achievements to Industrialized Project of YIXING (20130318023759).

\section{REFERENCES}

[1] C. L. Zhao, M. M. Zhang, W. L. Ma, et al., "Effect of Aluminum Flocculant on Microbe in Activated Sludge," Environmental Engineering, Vol. 18, No. 5, 2000, pp.
28-31.

[2] J.-H. Pan, C.-T. Jin and W.-Z. Wang, "Study on Aluminum Toxicity and Tolerance Mechanisms of Microorganisms," Acta Microbiologica Sinica, Vol. 44, No. 5, 2004, pp. 698-702.

[3] M. Hideahi, "Cell Biology of Aluminum Toxicity and Tolerance in Higher Plants," International Review of Cytology-A Survey of Cell Biology, Vol. 200, 2000, pp. $1-46$.

[4] L. L. Bao, Q. F. Cheng, D. Li, et al., "Silicon-Based Microfabricated Microbial Fuel Cell Toxicity Sensor," Water \& Wastewater Engineering, Vol. 36, No. 3, 2010, pp. 144-147.

[5] V. K. Leon, "Cellular Mechanisms of Aluminum Toxicity and Resistance in Plants," Annual Review of Plant Physiology and Plant Molecular Biology, Vol. 46, 1995, pp. 237-260. 